\title{
Effect and economic feasibility of preharvest spray of Calcium Nitrate, Boric Acid and Zinc Sulphate on yield attributing characters of Nagpur mandarin (Citrus reticulata blanco)
}

\begin{abstract}
An investigation was carried out during 2014-15 to study the effect of pre harvest spray of Calcium nitrate, Boric acid and Zinc sulphate on yield attributing characters of Nagpur mandarin. Various doses of Calcium nitrate $(1.0 \%, 2.0 \%$ and $3.0 \%)$, Boric acid $(0.2 \%, 0.4 \%$ and $0.6 \%)$ and Zinc sulphate $(0.2 \%, 0.4 \%$ and $0.6 \%)$ were sprayed before harvesting. The maximum increase in yield attributing characters like diameter of fruit, fruit weight, fruit volume, fruit yield/plant, estimated(yield/ha), maximum gross return, highest net profit and reduced peel thickness was recorded with T27 treatment combination (calcium nitrate $3.0 \%+$ boric acid $0.6 \%+$ Zinc sulphate $0.6 \%$ ) over control. Further, T24 treatment combination (calcium nitrate $3.0 \%+$ boric acid $0.4 \%+$ Zinc sulphate $0.6 \%$ ) has also significantly increased number of segments per fruit, and reduced number of seeds per fruit over control.
\end{abstract}

Keywords: pre harvest spray, calcium nitrate, Zinc sulphate, Boric acid, yield, economic feasibility
Volume I Issue I - 2017

Manish Kumar Meena,' MC Jain,' Jitendra Singh,' Manojkumar Sharma ${ }^{2}$

'Department of Fruit science, Agriculture University, India

2Department of Soil science, Agriculture University, India

Correspondence: Manish Kumar Meena, Department of Fruit science, College of Horticulture and Forestry, Jhalawar, Agriculture University, Kota, Rajasthan-326023, India, Email manishkhamrya@gmail.com

Received: May 02, 2017 | Published: September 22, 2017

\section{Introduction}

Nagpur Mandarin (Citrus reticulata Blanco.) which occupies the first position among the citrus in India with respect to area and production. It is considered one of the most important loose skinned oranges being commercially grown in Nagpur region of Maharashtra, Mandsaur district of Madhya Pradesh and Jhalawar District of Rajasthan State. In India, citrus fruits occupies a prominent place and extensively grown as tropical and subtropical fruits after mango and banana. The Fruit of Nagpur Santra are subglobose, with average weight $110-125 \mathrm{~g}$, rind medium thick, fairly loosely adherent, surface is relatively smooth, segment $10-15$ number and seeds $1-2$ per segment, peel colour pale orange fruits quality good. The total production of mandarin in India is 34.31 lakh tonnes from an area of 330.0 thousand hectares with the productivity of $10.4 \mathrm{MT} / \mathrm{ha}$. In Rajasthan mandarin covers 11.20 thousand hectares area producing 229.90 thousand MT with the productivity of $20.5 \mathrm{MT} / \mathrm{ha} .{ }^{1}$ The mineral nutrients play an important role in the development and growth of new cells in plant metabolism. The Calcium salts are known to be involved in a number of physiological processes concerning membrane structure, function and enzymatic activity. The calcium, like that of all minerals, is still obscure, but it is important for cell division and cell wall development. ${ }^{2}$ Zinc $(\mathrm{Zn})$ is an essential micro element for plants, being involved in many enzymatic reactions and is necessary for their good growth and development. Zinc improves the auxins content and it also acts as catalyst in oxidation-reduction processes. ${ }^{3}$ Boron is also a heavy metal micronutrient. It is absorbed by plant in the form of boric acid $\left(\mathrm{H}_{3} \mathrm{BO}_{3}\right)$. It is essential for translocation of sugar; involved in reproduction of plants and germination of pollen grains. ${ }^{4}$ Since the demand of fruit is increasing in the market, thereby to achieve higher yield of good quality fruit become the priority. The application of mineral nutrients like calcium nitrate, boric acid and zinc sulphate are known to play a crucial role in growth, development of fruits. The present study will contribute to ascertain the physical and biochemical status of Nagpur mandarin fruits at harvest as influenced by preharvest spray of mineral nutrients, which may help in increasing the yield Nagpur mandarin. Hence, the present studies were undertaken under Rajasthan conditions especially in Jhalawar with the followings objectives: To study the effect of pre harvest spray of calcium nitrate, boric acid and zinc sulphate on yield attributing characters and to work out economic feasibility of Nagpur mandarin.

\section{Materials and methods}

The present investigation was carried out on eight years old Nagpur mandarin (Citrus reticulata Blanco.) of uniform size and growth at the Fruit research farm, Department of Fruit Science, College of Horticulture and Forestry, Jhalawar during the year 2014-15. The selected plants were sprayed with Calcium nitrate (1.0, 2.0 and 3.0 per cent), Boric acid (0.2, 0.4 and 0.6 per cent) and Zinc sulphate $(0.2,0.4$ and 0.6 per cent).This experiment was laid out in Factorial Randomized Block Design (RBD) with three replications. The factors of experimentation comprising of 28 treatment combinations to study the effect of pre-harvest spray of Calcium nitrate, Zinc sulphate and Boric acid on yield and economic feasibility of Nagpur mandarin (Citrus reticulata Blanco). The treatments were applied during second week of September, 2014 after selection of good uniform size and bearing plants. The observations were recorded on different aspects viz. physical characteristics of fruits (diameter of fruit, peel thickness, fruit weight, fruit volume, number of fruits per plant, number of sacs per fruit, number of seeds per fruit. The data generated during the experimentation were subjected to statistical analysis of variance. The significance of the treatments was tested through ' $F$ ' test at 5 per cent level of significance. The critical difference was calculated to assess the significance of difference among the different treatments as described by Fisher 


\section{Result and discussion}

\section{Yield attributing characters}

Diameter of fruit $(\mathbf{c m})$ : The data in reveals that interaction effect of calcium nitrate, boric acid and zinc sulphate was significant on diameter of fruits. The maximum increase in horizontal diameter (7.89 $\mathrm{cm})$ and vertical diameter $(7.58 \mathrm{~cm})$ was observed with treatment T27 (Calcium nitrate @ 3.0\%+boric acid@0.6\% + zinc sulphate @ $0.6 \%$ ), which was closely followed by T23, T26, T24, T22 and T21 treatments. The higher fruit diameter due to combined application of calcium, boron and zinc may be attributed to their stimulatory effect of plant metabolism and better augmentation in cell division and cell elongation of cells. The results are in conformity with the observations recorded by Trivedi et al. ${ }^{6}$ in Guava, Razzaq et al. ${ }^{7}$ in Kinnow and
Meena et al. ${ }^{8}$ in Guava.

Peel thickness (mm): The data in (Table 1) reveals that interaction effect of calcium nitrate, boric acid and zinc sulphate was significantly observed on peel thickness. The minimum peel thickness $(3.21 \mathrm{~mm})$ of fruit was recorded with the treatment $\mathrm{T}_{27}$ (Calcium nitrate @ 3.0\%+boric acid@0.6\%+zinc sulphate@0.6\%) and which was closely followed by $\mathrm{T}_{24}, \mathrm{~T}_{26}, \mathrm{~T}_{22}$ and $\mathrm{T}_{25}$ treatments. However, the maximum peel thickness of fruit $(4.86 \mathrm{~mm})$ was recorded under control. The reduction in peel thickness might be attributed to the synergistic effect of boric acid+zinc sulphate and prevailing climatic condition during harvesting of fruit. The present results are in close conformity with the finding of Haque et al. ${ }^{4}$ in Mandarin, Razzaq et al. ${ }^{7}$ in kinnow.

Table I Effect of pre-harvest spray of calcium nitrate, boric acid and zinc sulphate on physical characteristics of Nagpur mandarin (Citrus reticulata Blanco)

\begin{tabular}{|c|c|c|c|c|c|c|}
\hline \multirow[t]{2}{*}{ Treatments } & & \multicolumn{2}{|c|}{ Diameter of fruits $(\mathrm{cm})$} & \multirow[t]{2}{*}{ Peel thickness $(\mathrm{mm})$} & \multirow[t]{2}{*}{ Fruit weight (g) } & \multirow[t]{2}{*}{ Fruit volume (cc) } \\
\hline & & Horizontal & Vertical & & & \\
\hline $\mathbf{T}_{0}$ & $\mathrm{Ca}_{0} \mathrm{~B}_{0} \mathrm{Zn}_{0}$ & 6.11 & 5.18 & 4.86 & $|13.6|$ & 138.03 \\
\hline $\mathbf{T}_{1}$ & $\mathrm{Ca}_{1} \mathrm{~B}_{1} \mathrm{Zn}_{1}$ & 6.22 & 5.56 & 4.78 & 122.67 & 148.79 \\
\hline $\mathbf{T}_{2}$ & $\mathrm{Ca}_{1} \mathrm{~B}_{1} \mathrm{Zn}_{2}$ & 6.48 & 5.65 & 4.52 & 125.83 & 149.45 \\
\hline $\mathbf{T}_{3}$ & $\mathrm{Ca}_{1} \mathrm{~B}_{1} \mathrm{Zn}_{3}$ & 6.58 & 5.78 & 4.39 & 130.53 & 152.82 \\
\hline $\mathbf{T}_{4}$ & $\mathrm{Ca}_{1} \mathrm{~B}_{2} \mathrm{Zn}_{1}$ & 6.8 & 5.82 & 3.97 & 132.34 & 160 \\
\hline$T_{5}$ & $\mathrm{Ca}_{1} \mathrm{~B}_{2} \mathrm{Zn}_{2}$ & 6.79 & 5.98 & 4.29 & 129.28 & 156.29 \\
\hline $\mathbf{T}_{6}$ & $\mathrm{Ca}_{1} \mathrm{~B}_{2} \mathrm{Zn}_{3}$ & 6.85 & 5.6 & 3.82 & 138.3 & 156.24 \\
\hline $\mathbf{T}_{7}$ & $\mathrm{Ca}_{1} \mathrm{~B}_{3} \mathrm{Zn}_{1}$ & 6.92 & 5.98 & 3.83 & 140.11 & 170.16 \\
\hline $\mathbf{T}_{8}$ & $\mathrm{Ca}_{1} \mathrm{~B}_{3} \mathrm{Zn}_{2}$ & 6.66 & 6.02 & 3.79 & 130.22 & 157.82 \\
\hline $\mathbf{T}_{9}$ & $\mathrm{Ca}_{1} \mathrm{~B}_{3} \mathrm{Zn}_{3}$ & 7.12 & 6.44 & 3.53 & 140.08 & 168.55 \\
\hline$T_{10}$ & $\mathrm{Ca}_{2} \mathrm{~B}_{1} \mathrm{Zn}_{1}$ & 6.88 & 6.34 & 3.72 & 147.98 & 173.22 \\
\hline$T_{11}$ & $\mathrm{Ca}_{2} \mathrm{~B}_{1} \mathrm{Zn}_{2}$ & 6.94 & 5.95 & 3.69 & 140.12 & 167.45 \\
\hline$T_{12}$ & $\mathrm{Ca}_{2} \mathrm{~B}_{1} \mathrm{Zn}_{3}$ & 7.38 & 6.42 & 3.77 & 141.36 & 171.32 \\
\hline$T_{13}$ & $\mathrm{Ca}_{2} \mathrm{~B}_{2} \mathrm{Zn}$ & 7.41 & 6.54 & 3.78 & 148.97 & 175.22 \\
\hline$T_{14}$ & $\mathrm{Ca}_{2} \mathrm{~B}_{2} \mathrm{Zn}_{2}$ & 7.43 & 6.76 & 3.74 & 139.32 & 171.11 \\
\hline$T_{15}$ & $\mathrm{Ca}_{2} \mathrm{~B}_{2} \mathrm{Zn}_{3}$ & 7.39 & 6.38 & 3.66 & 150.19 & 178.82 \\
\hline$T_{16}$ & $\mathrm{Ca}_{2} \mathrm{~B}_{3} \mathrm{Zn}$ & 7.48 & 6.85 & 3.67 & 142.78 & 167.17 \\
\hline$T_{17}$ & $\mathrm{Ca}_{2} \mathrm{~B}_{3} \mathrm{Zn}_{2}$ & 7.52 & 7.05 & 3.65 & 151.07 & 178.33 \\
\hline$T_{18}$ & $\mathrm{Ca}_{2} \mathrm{~B}_{3} \mathrm{Zn}_{3}$ & 7.11 & 6.92 & 3.50 & 144.83 & 176.12 \\
\hline$T_{19}$ & $\mathrm{Ca}_{3} \mathrm{~B}_{1} \mathrm{Zn}$ & 7.53 & 6.22 & 3.57 & 153.42 & 183.11 \\
\hline$T_{20}$ & $\mathrm{Ca}_{3} \mathrm{~B}_{1} \mathrm{Zn}_{2}$ & 7.42 & 7.08 & 3.67 & 150.99 & $|78.3|$ \\
\hline $\mathbf{T}_{21}$ & $\mathrm{Ca}_{3} \mathrm{~B}_{1} \mathrm{Zn}_{3}$ & 7.70 & 7.23 & 3.67 & 145.54 & 176.23 \\
\hline$T_{22}$ & $\mathrm{Ca}_{3} \mathrm{~B}_{2} \mathrm{Zn}$ & 7.77 & 7.27 & 3.38 & 147.44 & 176.57 \\
\hline$T_{23}$ & $\mathrm{Ca}_{3} \mathrm{~B}_{2} \mathrm{Zn}_{2}$ & 7.83 & 7.47 & 3.57 & 157.33 & 187.34 \\
\hline $\mathbf{T}_{24}$ & $\mathrm{Ca}_{3} \mathrm{~B}_{2} \mathrm{Zn}_{3}$ & 7.78 & 7.31 & 3.27 & 158.89 & 189.37 \\
\hline $\mathbf{T}_{25}$ & $\mathrm{Ca}_{3} \mathrm{~B}_{3} \mathrm{Zn} \mathrm{n}_{1}$ & 7.31 & 6.93 & 3.48 & 153.78 & 183.87 \\
\hline$T_{26}$ & $\mathrm{Ca}_{3} \mathrm{~B}_{3} \mathrm{Zn}_{2}$ & 7.82 & 7.44 & 3.33 & 157.33 & 187.86 \\
\hline $\mathbf{T}_{27}$ & $\mathrm{Ca}_{3} \mathrm{~B}_{3} \mathrm{Zn}_{3}$ & 7.89 & 7.58 & 3.21 & 160.72 & 190.14 \\
\hline CD at $5 \%$ & & 0.14 & 0.16 & 0.07 & 2.73 & 3.75 \\
\hline SEm \pm & & $0.4 I$ & 0.46 & 0.21 & 7.77 & 10.63 \\
\hline
\end{tabular}

Here,

Cal - Calcium nitrate- I\% BI - Boric acid - $0.2 \%, \mathrm{ZnI}$ - Zinc sulphate $-0.2 \%$

Ca2 - Calcium nitrate $-2 \%$ B2 - Boric acid - 0.4\%, Zn2 - Zinc sulphate $-0.4 \%$

Ca3 - Calcium nitrate $-3 \%$ B3 - Boric acid - 0.6\%, Zn3 - Zinc sulphate $-0.6 \%$

Citation: Meena MK, Jain MC, Singh, et al. Effect and economic feasibility of preharvest spray of Calcium Nitrate, Boric Acid and Zinc Sulphate on yield attributing characters of Nagpur mandarin (Citrus reticulata blanco). Horticult Int J. 20I7; I (I):23-28. DOI: 10.15406/hij.2017.01.00004 
Fruit weight (gm) and Volume (cc): The data in Table 1 narrates that fruit weight and fruit volume of Nagpur mandarin increased significantly by the application of calcium nitrate, boric acid and zinc sulphate. The maximum fruit weight (160.72 g) and volume (190.14 cc) were recorded with treatment $\mathrm{T}_{27}$ (Calcium nitrate @ 3.0\%+boric acid@0.6\%+zinc sulphate@0.6\%). The minimum fruit weight and volume $(113.61 \mathrm{~g})$ and $138.03 \mathrm{cc})$ were measured under control. The increase in fruit weight and volume might be due to increased rate of cell division and cell enlargement leading to more accumulation of photosynthates in the fruit and better translocation of photosynthates enabling optimum source: sink ratio as a result of boron application as reported by Abd-Allah. ${ }^{9}$ The findings are similar to those reported by Babu et al. ${ }^{2}$ in Kinnow and Meena et al. ${ }^{8}$ in Ber.

Number of seeds per fruit: The data in Table 2 reveals that interaction effect of calcium nitrate, boric acid and zinc sulphate was significant on number of seeds per fruit. The minimum number of seeds per fruit (6.33) was recorded with treatment $\mathrm{T}_{24}$ (calcium nitrate @ 3 per cent+boric acid@0.4 per cent+zinc sulphate@0.6 per cent) which was closely followed by $\mathrm{T}_{27}, \mathrm{~T}_{26}, \mathrm{~T}_{21}, \mathrm{~T}_{22}$ and $\mathrm{T}_{23}$ treatments. However, the maximum number of number of seed per fruit (9.89) was recorded in control. The present results are in consonance with the findings of Haque et al. ${ }^{4}$ in Mandarin and Sharma et al. ${ }^{10}$ in Kagzi lime.

Table 2 Effect of pre-harvest spray of calcium nitrate, boric acid and zinc sulphate on yield attributes characters of Nagpur mandarin

\begin{tabular}{|c|c|c|c|c|c|c|}
\hline Treatments & & $\begin{array}{l}\text { No. of seeds I } \\
\text { fruit }\end{array}$ & $\begin{array}{l}\text { No. of sacs I } \\
\text { fruit }\end{array}$ & $\begin{array}{l}\text { No. of fruits per } \\
\text { plant }\end{array}$ & $\begin{array}{l}\text { Yield per plant } \\
(\mathrm{kg})\end{array}$ & $\begin{array}{l}\text { Estimated yield (Tones } \\
\text { / ha.) }\end{array}$ \\
\hline $\mathbf{T}_{0}$ & $\mathrm{Ca}_{0} \mathrm{~B}_{0} \mathrm{Zn}_{0}$ & 9.89 & 9 & 97.67 & 11.27 & 3.55 \\
\hline $\mathbf{T}_{1}$ & $\mathrm{Ca}_{1} \mathrm{~B}_{1} \mathrm{Zn}_{1}$ & 9.78 & 9.89 & 100.33 & 12.06 & 3.69 \\
\hline $\mathbf{T}_{2}$ & $\mathrm{Ca}_{1} \mathrm{~B}_{1} \mathrm{Zn}_{2}$ & 9.78 & 9.67 & 107.00 & 12.11 & 3.77 \\
\hline $\mathbf{T}_{3}$ & $\mathrm{Ca}_{1} \mathrm{~B}_{1} \mathrm{Zn}_{3}$ & 9.42 & 9.89 & 109.00 & 12.33 & 3.94 \\
\hline $\mathbf{T}_{4}$ & $\mathrm{Ca}_{1} \mathrm{~B}_{2} \mathrm{Zn}_{1}$ & 9.67 & 10.33 & 108.00 & 13.77 & 4.02 \\
\hline $\mathbf{T}_{5}$ & $\mathrm{Ca}_{1} \mathrm{~B}_{2} \mathrm{Zn}_{2}$ & 9.67 & 10.11 & 110.67 & 15.22 & 4.14 \\
\hline $\mathbf{T}_{6}$ & $\mathrm{Ca}_{1} \mathrm{~B}_{2} \mathrm{Zn}_{3}$ & 9.23 & 10.78 & 118.00 & 14.33 & 4.24 \\
\hline $\mathbf{T}_{7}$ & $\mathrm{Ca}_{1} \mathrm{~B}_{3} \mathrm{Zn}_{1}$ & 8.94 & 10.44 & 117.67 & 15.78 & 3.92 \\
\hline $\mathbf{T}_{8}$ & $\mathrm{Ca}_{1} \mathrm{~B}_{3} \mathrm{Zn}_{2}$ & 9.12 & 10.78 & 110.67 & 16.39 & 4.14 \\
\hline $\mathbf{T}_{9}$ & $\mathrm{Ca}_{1} \mathrm{~B}_{3} \mathrm{Zn}_{3}$ & 8.89 & 10.00 & 118.54 & 16.22 & 4.62 \\
\hline$T_{10}$ & $\mathrm{Ca}_{2} \mathrm{~B}_{1} \mathrm{Zn}_{1}$ & 9.12 & 10.33 & 120.00 & 15.78 & 4.27 \\
\hline $\mathbf{T}_{11}$ & $\mathrm{Ca}_{2} \mathrm{~B}_{1} \mathrm{Zn}_{2}$ & 8.89 & 10.78 & 121.33 & 17.34 & 4.42 \\
\hline$T_{12}$ & $\mathrm{Ca}_{2} \mathrm{~B}_{1} \mathrm{Zn}_{3}$ & 9.12 & II.II & 118.33 & 17.77 & 4.77 \\
\hline$T_{13}$ & $\mathrm{Ca}_{2} \mathrm{~B}_{2} \mathrm{Zn}_{1}$ & 8.78 & 10.67 & 125.33 & 17.92 & 4.64 \\
\hline$T_{14}$ & $\mathrm{Ca}_{2} \mathrm{~B}_{2} \mathrm{Zn}_{2}$ & 8.5 & 11.44 & 119.00 & 17.11 & 4.96 \\
\hline $\mathbf{T}_{15}$ & $\mathrm{Ca}_{2} \mathrm{~B}_{2} \mathrm{Zn}_{3}$ & 8.24 & 10.89 & 119.00 & 18.37 & 5.27 \\
\hline$T_{16}$ & $\mathrm{Ca}_{2} \mathrm{~B}_{3} \mathrm{Zn}_{1}$ & 8.37 & 11.78 & 120.00 & 18.44 & 5.12 \\
\hline$T_{17}$ & $\mathrm{Ca}_{2} \mathrm{~B}_{3} \mathrm{Zn}_{2}$ & 8.10 & 11.00 & 118.34 & 19.55 & 5.42 \\
\hline $\mathbf{T}_{18}$ & $\mathrm{Ca}_{2} \mathrm{~B}_{3} \mathrm{Zn}_{3}$ & 7.96 & 11.78 & 125.67 & 19.78 & 5.74 \\
\hline$T_{19}$ & $\mathrm{Ca}_{3} \mathrm{~B}_{1} \mathrm{Zn}_{1}$ & 8.10 & 10.89 & 121.34 & 19.04 & 5.82 \\
\hline $\mathbf{T}_{20}$ & $\mathrm{Ca}_{3} \mathrm{~B}_{1} \mathrm{Zn}_{2}$ & 7.78 & 11.67 & 121.67 & 18.99 & 5.94 \\
\hline$T_{21}$ & $\mathrm{Ca}_{3} \mathrm{~B}_{1} \mathrm{Zn}_{3}$ & 7.44 & 12.00 & 125.67 & 20.33 & 6.04 \\
\hline $\mathbf{T}_{22}$ & $\mathrm{Ca}_{3} \mathrm{~B}_{2} \mathrm{Zn} \mathrm{n}_{1}$ & 7.67 & 11.78 & 128.23 & 20.11 & 5.85 \\
\hline $\mathbf{T}_{23}$ & $\mathrm{Ca}_{3} \mathrm{~B}_{2} \mathrm{Zn}_{2}$ & 7.67 & 12.33 & 130.78 & 21.1 & 6.18 \\
\hline $\mathbf{T}_{24}$ & $\mathrm{Ca}_{3} \mathrm{~B}_{2} \mathrm{Zn}_{3}$ & 6.33 & 12.56 & 132.33 & 21.48 & 6.28 \\
\hline$T_{25}$ & $\mathrm{Ca}_{3} \mathrm{~B}_{3} \mathrm{Zn}_{1}$ & 7.78 & 11.44 & 128.67 & 20.77 & 6.11 \\
\hline$T_{26}$ & $\mathrm{Ca}_{3} \mathrm{~B}_{3} \mathrm{Zn}_{2}$ & 7.14 & 11.89 & $131.1 \mid$ & 21.37 & 6.23 \\
\hline $\mathbf{T}_{27}$ & $\mathrm{Ca}_{3} \mathrm{~B}_{3} \mathrm{Zn}_{3}$ & 6.82 & 12.22 & 134.43 & 21.67 & 6.32 \\
\hline CD at $5 \%$ & & 0.23 & 0.27 & 2.77 & 0.39 & 0.10 \\
\hline SEm \pm & & 0.65 & 0.76 & 7.87 & 1.11 & 0.31 \\
\hline
\end{tabular}

Here,

Cal - Calcium nitrate- I\% BI - Boric acid - $0.2 \%, \mathrm{ZnI}-$ Zinc sulphate $-0.2 \%$

Ca2 - Calcium nitrate $-2 \%$ B2 - Boric acid $-0.4 \%$, Zn2 - Zinc sulphate $-0.4 \%$

Ca3 - Calcium nitrate - 3\% B3 - Boric acid - 0.6\%, Zn3 - Zinc sulphate $-0.6 \%$ 
Number of segments per fruit: The data in Table 2 reveal that interaction effect of calcium nitrate, boric acid and zinc sulphate was significant on number of segments per fruit. The maximum number of segments per fruit (12.56) was recorded with treatment $\mathrm{T}_{24}$ (calcium nitrate@3.0\%+boric acid@0.4\%+zinc sulphate@0.6\%) which was closely followed by $\mathrm{T}_{23}, \mathrm{~T}_{27}, \mathrm{~T}_{21}$ and $\mathrm{T}_{26}$ treatments. However, the minimum number of number of segments per fruit (9.00) was recorded in control. The variation in the number of segments per fruit due to combination of different micronutrients might be attributed to difference in enzyme ion alluding during cell division and cell differentiation phases of fruit development. The present results are in conformity with the findings of Razzaq et al. ${ }^{7}$ in kinnow, and Khan et al. ${ }^{3}$ in Kinnow.

Number of fruits per plant: The maximum number of fruits per plant (134.43) was recorded with treatment $\mathrm{T}_{27}$ (calcium nitrate @ 3.0\%+boric acid@0.6\%+zinc sulphate@ @ 0.6\%) treatments. It was closely followed by $\mathrm{T}_{24} \mathrm{~T}_{26}$ and $\mathrm{T}_{23}$ treatments. However, the minimum number of fruits per plant (97.67) was recorded in control. The increase in number of fruits by application of micronutrient treatments may be due to reduction in fruit drop as a result of zinc, boron and calcium application which resulted in higher number of fruits and zinc plays a pivotal role in enhancing auxin concentration by counteracting fruit drop, thereby minimizing the economic losses and supplementing the yield. The present results are in conformity with the findings of Haque et al. ${ }^{4}$ in mandarin and Razzaq et al. ${ }^{7}$ in kinnow.

Fruit yield in $\mathbf{~ k g} /$ tree: The data in Table 2 indicated that the interaction effect of calcium nitrate, zinc sulphate and boric acid was significantly observed on fruit yield in $\mathrm{kg} / \mathrm{tree}$ and tonnes/ha. The fruit yield of Nagpur mandarin $(21.67 \mathrm{~kg} /$ tree and 6.32 tonnes $/$ ha $)$ recorded maximum with treatment T27 (calcium nitrate@3.0\%+boric acid@ 0.6\%+zinc sulphate @ 0.6\%) which was at par with T24, T26, T23 and T25 treatments. However, the minimum fruit yield (11.27) kg/ tree and 3.55 tonnes/ha) was recorded in control. The increase in yield of Nagpur mandarin fruits by application of micronutrient treatments may be due to the direct or indirect involvement of nutrients which provide better mobilization of nutrients, amino acids and metabolites for the growth and development of fruits by spurt in metabolic activities and catalytic cellular pathways. These activities favour the plant system to improve their size, weight and volume and thereby synergistically increased the total yield of Nagpur mandarin. The present results are in conformity with the findings of Abd-Allah ${ }^{2}$ in Orange and Patil et al. ${ }^{11}$ in Kinnow.

\section{Economics feasibility}

The economics of different micronutrient treatments used at various concentrations in the present investigation was calculated and presented in Table 3. The economic feasibility calculated for various treatments showed that the application of $\mathrm{T}_{27}$ (calcium nitrate @ 3.0\%+boric acid@0.6\%+Zinc sulphate@0.6\%) treatment has resulted the maximum gross return of Rs. 1,26,400/ha which was Rs. 55,400/ha excess over control and with highest net profit (Rs. 48,560/ha) which was 78.03 per cent higher than control, which was followed by $\mathrm{T}_{24}$ (calcium nitrate @ 3.0\%+boric acid @ 0.4\%+Zinc sulphate@0.6\%) and $\mathrm{T}_{26}$ (calcium nitrate@3.0\%+boric acid @ $0.6 \%+$ Zinc sulphate@ $0.4 \%$ ) having net profit values of Rs. 48, 272 and Rs. 47,208 which was 76.90 per cent and 75.49 per cent higher than control, respectively.

Table 3 Economic feasibility of Pre harvest spray of micronutrient treatments in Nagpurmandarin

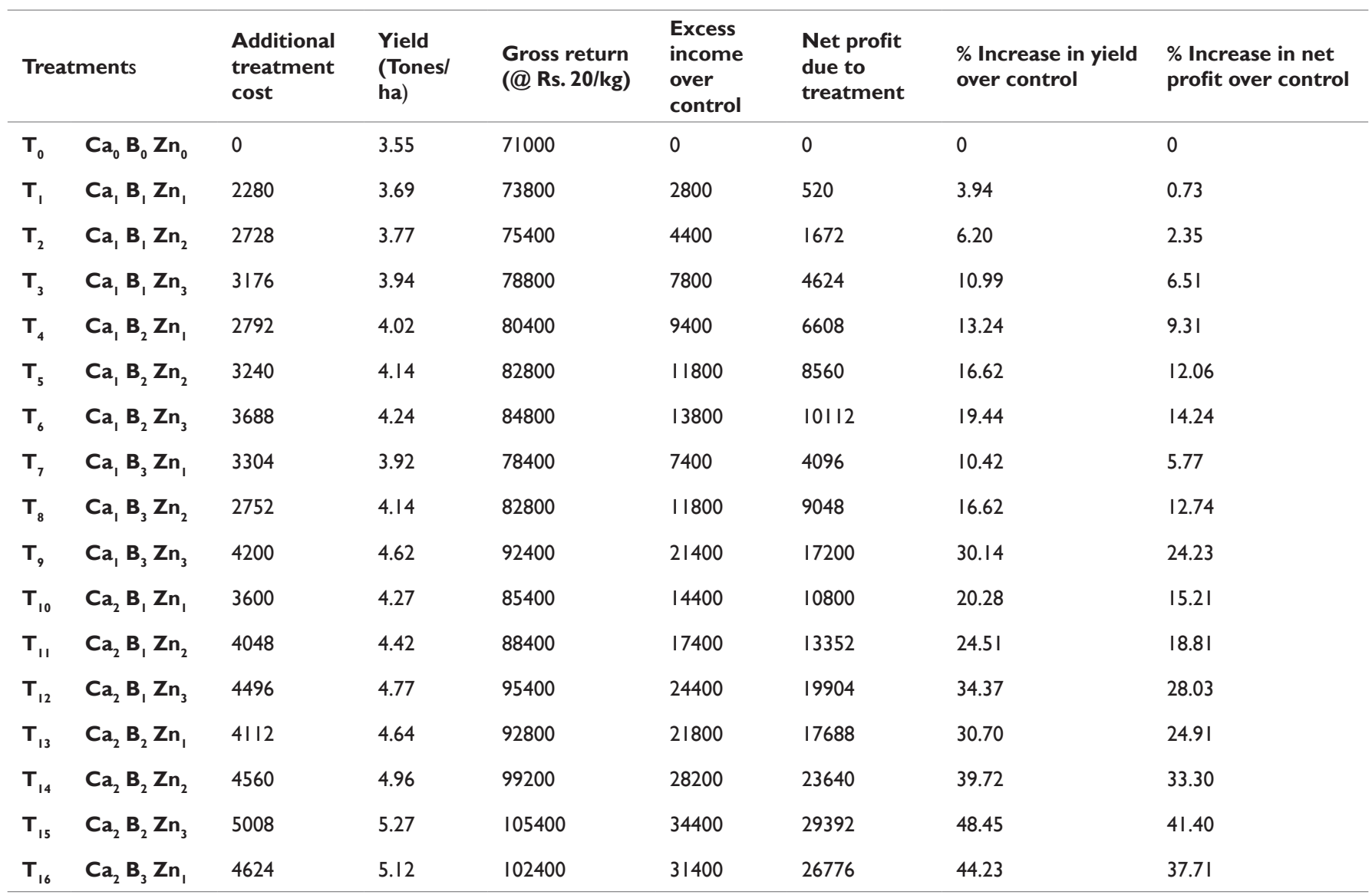


Table Continued....

\begin{tabular}{|c|c|c|c|c|c|c|c|c|}
\hline \multicolumn{2}{|c|}{ Treatments } & \multirow{2}{*}{$\begin{array}{l}\text { Additional } \\
\text { treatment } \\
\text { cost }\end{array}$} & \multirow{2}{*}{$\begin{array}{l}\text { Yield } \\
\text { (Tones/ } \\
\text { ha) }\end{array}$} & \multirow{2}{*}{$\begin{array}{l}\text { Gross return } \\
\text { (@ Rs. 20/kg) } \\
108400\end{array}$} & \multirow{2}{*}{$\begin{array}{l}\text { Excess } \\
\text { income } \\
\text { over } \\
\text { control }\end{array}$} & \multirow{2}{*}{$\begin{array}{l}\text { Net profit } \\
\text { due to } \\
\text { treatment }\end{array}$} & \multirow{2}{*}{$\begin{array}{l}\% \text { Increase in yield } \\
\text { over control } \\
52.68\end{array}$} & \multirow{2}{*}{$\begin{array}{l}\text { \% Increase in net } \\
\text { profit over control } \\
45.53\end{array}$} \\
\hline $\mathbf{T}_{17}$ & $\mathrm{Ca}_{2} \mathrm{~B}_{3} \mathrm{Zn}_{2}$ & & & & & & & \\
\hline$T_{18}$ & $\mathrm{Ca}_{2} \mathrm{~B}_{3} \mathrm{Zn}_{3}$ & 5520 & 5.74 & | | 4800 & 43800 & 38280 & 61.69 & 53.92 \\
\hline $\mathbf{T}_{19}$ & $\mathrm{Ca}_{3} \mathrm{~B}_{1} \mathrm{Zn}_{1}$ & 4920 & 5.82 & I I 6400 & 45400 & 40480 & 63.94 & 57.01 \\
\hline$T_{20}$ & $\mathrm{Ca}_{3} \mathrm{~B}_{1} \mathrm{Zn}_{2}$ & 5368 & 5.94 & 118800 & 47800 & 42432 & 67.32 & 59.76 \\
\hline $\mathbf{T}_{21}$ & $\mathrm{Ca}_{3} \mathrm{~B}_{1} \mathrm{Zn}_{3}$ & 5816 & 6.04 & 120800 & 49800 & 43984 & 70.14 & 61.95 \\
\hline $\mathbf{T}_{22}$ & $\mathrm{Ca}_{3} \mathrm{~B}_{2} \mathrm{Zn}$ & 5432 & 5.85 & 117000 & 46000 & 40568 & 64.79 & 57.14 \\
\hline $\mathbf{T}_{23}$ & $\mathrm{Ca}_{3} \mathrm{~B}_{2} \mathrm{Zn}_{2}$ & 5880 & 6.18 & 123600 & 52600 & 46720 & 74.08 & 65.8 \\
\hline $\mathbf{T}_{24}$ & $\mathrm{Ca}_{3} \mathrm{~B}_{2} \mathrm{Zn}_{3}$ & 6328 & 6.28 & 125600 & 54600 & 48272 & 76.90 & 67.99 \\
\hline $\mathbf{T}_{26}$ & $\mathrm{Ca}_{3} \mathrm{~B}_{3} \mathrm{Zn}_{2}$ & 6392 & 6.23 & 124600 & 53600 & 47208 & 75.49 & 66.49 \\
\hline $\mathbf{T}_{27}$ & $\mathrm{Ca}_{3} \mathrm{~B}_{3} \mathrm{Zn}_{3}$ & 6840 & 6.32 & 126400 & 55400 & 48560 & 78.03 & 68.39 \\
\hline
\end{tabular}

Here,

$\mathrm{Ca}_{1}-$ Calcium nitrate- $1 \% \mathrm{~B}_{1}-$ Boric acid $-0.2 \%, \mathrm{Zn}_{1}-$ Zinc sulphate $-0.2 \%$

$\mathrm{Ca}_{2}-$ Calcium nitrate $-2 \% \mathrm{~B}_{2}-$ Boric acid $-0.4 \%, \mathrm{Zn}_{2}-$ Zinc sulphate $-0.4 \%$

$\mathrm{Ca}_{3}-$ Calcium nitrate $-3 \% \mathrm{~B}_{3}-$ Boric acid $-0.6 \%, \mathrm{Zn}_{3}-$ Zinc sulphate $-0.6 \%$

The highest percent increase in net profit due to calcium nitrate @3.0\%+boric acid@0.6\%+Zinc sulphate @ 0.6\%) $\left(\mathrm{T}_{27}\right)$ treatment may be because of highest yield under this treatment as evident from the present results discussed earlier in the text. Therefore, among the various micronutrient treatments attempted under present investigation, the application of calcium nitrate@3.0\%+boric acid@0.6\%+Zinc sulphate @ $0.6 \%)\left(\mathrm{T}_{27}\right)$ was found to be most economic and desirable treatment. The relative economics of the various micronutrient treatments was also worked out. On the basis of relative economics it can again be suggested that calcium nitrate @ 3.0\%+boric acid@0.6\%+Zinc sulphate@0.6\% treatment was found to be most effective and desirable on the basis of highest yield of Nagpur mandarin fruit.

\section{Conclusion}

On the basis of results obtained from the field experiment, it may be concluded that the pre-harvest spray of different micronutrients was found beneficial for yield attributes and economic feasibility of Nagpur mandarin. Among different doses, the application of $\mathrm{T}_{27}$ treatment was found best with regards to maximum increment in fruit weight, fruit volume, diameter of fruit (horizontal and vertical), reduced peel thickness, number of fruits per plant, fruit yield per plant, estimated yield tonnes/ha, gross return, highest net profit. Further $\mathrm{T}_{24}$ treatment combination (calcium nitrate@3.0\%+boric acid@ $0.4 \%+$ Zinc sulphate @ 0.6\%) has also given maximum increased number of segments per fruit and reduction in number of seeds per fruit. Therefore, based on the present research it may be concluded that, in Nagpur mandarin the pre harvest spray of calcium nitrate @ $3.0 \%$ +boric acid @ 0.6\%+Zinc sulphate@0.6\% before harvesting at early stage of fruit development may improve the yield characteristics of Mandarin. ${ }^{12}$

\section{Acknowledgements}

\section{Conflict of interest}

The author declares no conflict of interest.

\section{References}

1. Indian Horticulture. National Horticulture Board, Gurgaon, India; 2015. p. $118-121$.

2. Babu KD, Yadav DS. Foliar spray of micronutrients for yield and quality improvement in Khasi mandarin (Citrus reticulata Blanco.) Indian Journal of Horticulture. 2005;62(3):280-281.

3. Khan AS, Nasir M, Malik AU, et al. Effect of calcium, boron and zinc on the leaf mineral status, growth, productivity and fruit quality of 'Kinnow' mandarin (Citrus nobilis Lour $x$ Citrus deliciosa Tenora). Journal of Plant Nutrition. 2015;38(6):821-838.

4. Haque R, Roy A, Pramanick M. Response of foliar application of $\mathrm{Ca}$, $\mathrm{Zn}$, and $\mathrm{B}$ on improvement of growth and yield of mandarin orange in Darjeeling hills of West Bengal. Horticultural Journal. 2000;13(2):1520.

5. Fisher RA. Statistical methods for research workers. 11th edition. Oliver and Boyd, UK; 1950

6. Trivedi N, Singh D, Bahadur V, et al. Effect of foliar application of zinc and boron on yield of guava (Psidium guajava L.). Hort Flora Research Spectrum. 2012;1(3):281-283.

7. Razzaq K, Khan AS, Malik AU, et al. Foliar application of zinc influences the leaf mineral status, vegetative and reproductive growth, and yield and fruit quality of 'kinnow' mandarin. Journal of Plant Nutrition. 2013;36(10):1479-1495.

8. Meena VS, Yadav PK, Meena PM. Yields attributes of ber (Ziziphus mauritiana) CV. Gola as influenced by foliar application of ferrous sulphate and borax. Agric Sci Digest. 2008;28(3):219-221.

9. Abd Allah AS. Effect of spraying some macro and micro nutrients on fruit set, yield and fruit quality of Washington Navel orange trees. Journal of Applied Sciences Research. 2006;2(11):1059-1063. 
10. Sharma AK, Singh K, Mishra SP. Effect of foliar spray of zinc sulphate 2 , 4, 5-T and GA3 on quality of Kagzi lime (Citrus aurantifolia Swingle). Orissa Journal of Horticulture. 2002;30(2):115-118.

11. Patil DR, MS, Shafeeq LB, et al. Studies on the influence of micronutrient on growth, yield and quality of Kinnow mandarin. Trends in Biosciences. 2014;7(9):786-788.
12. Sajid M, Rab A, Tanveer S, et al. Pre-harvest treatment of Zn \& B affects the fruit quality and storability of sweet orange. J Agric Sci and Technology. 2012;2(2):1224-1233. 